\title{
Analogues of Parthenin and their antibacterial activity ${ }^{1}$
}

\author{
C. Ramesh, K. Harakishore, U.S.N. Murty, and Biswanath Das* \\ Organic Chemistry Division-I, Indian Institute of Chemical Technology, Uppal Road \\ Hyderabad 500 007, India \\ E-mail: biswanathdas@yahoo.com
}

\section{Dedicated to Professor Asima Chatterjee on her $85^{\text {th }}$ birthday}

(received 01 Oct 03; accepted 06 March 04; published on the web 12 March 04)

\begin{abstract}
Regio- and stereoselective chemical modifications of parthenin, a naturally occurring pseudoguaianolide, afforded its various natural and unnatural analogues whose antibacterial activity was studied. Parthenin itself and some of the analogues showed significant activity and with only one exception all of the active compounds were found to contain an intact $\alpha$ methylene- $\gamma$-butyrolactone moiety.
\end{abstract}

Keywords: Parthenin, pseudoguaianolide, analogues, antibacterial activity, $\alpha$-methylene- $\gamma-$ butyrolactone

\section{Introduction}

Parthenin $(\mathbf{1})^{2}$ is a major constituent of the aggressive and obnoxious herb, Parthenium hysterophorus L (Compositae). The compound is a sesquiterpenoid having a pseudoguaianolide structure. It contains an $\alpha$-methylene- $\gamma$-butyrolactone moiety (rind $\mathrm{C}$ ) along with other functionalities and five chiral centers. The compound is interesting for its structural pattern ${ }^{2}$ as well as for its bioactivity including antimalarial, ${ }^{3}$ antiamoebic, ${ }^{4}$ and allelopathic properties. ${ }^{5}$ Here we report the preparation of different analogues of the compound and our studies on their antibacterial activity. 


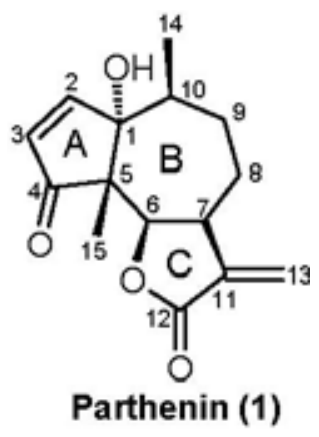

\section{Results and Discussion}

Parthenin (1) was treated with various chemical reagents for its regio- and stereoselective modifications at the $\mathrm{A}, \mathrm{B}$ and $\mathrm{C}$ rings to produce its different analogues (Scheme 1). The compound was reacted with acetic anhydride in the presence of sodium hydrogen sulfate supported on silica gel (NaHSO4.SiO2) ${ }^{6}$ as a catalyst at room temperature. The conversion solely led to the formation of the naturally occurring sesquiterpenoid, anhydroparthenin $(2)^{7}$. The same catalyst (NaHSO4.SiO2) was also used for transformation of $\mathbf{1}$ by treatment with trimethyl orthoformate (TMOF). The product was characterized from its physical and spectral (1H NMR and MS) properties as the known compound $2-\alpha$-methyl coronopilin $(3),{ }^{8}$ which is the 2-Omethyl analogue of the natural sesquiterpenoid isoxathin. ${ }^{9}$ On reaction with $\mathrm{NaN} 3$ and ceric ammonium nitrate (CAN), parthenin afforded the new compound 2- $\alpha$-azidocoronopilin (4). The structure of 4 was established from its spectral ( ${ }^{1} \mathrm{H}$ NMR and MS) and analytical data. The configuration of $\mathrm{H}-2$ was settled ${ }^{8}$ by observation of the position and splitting pattern of the signal for the proton ( $\delta 4.46, \mathrm{dd}, \mathrm{J}=9.8,8.0 \mathrm{~Hz}$ ) in the ${ }^{1} \mathrm{H}$ NMR spectrum. Moreover, $\mathrm{H}-2$ of 4 showed clear correlation with $\mathrm{H}_{3}-15$ in the NOESY experiment. In all of these three analogues, 2-4 the $\alpha$ methylene- $\gamma$-butyrolactone moiety (ring C) of parthenin (1) was intact.

Reduction of parthenin (1) with polymethylhydrosiloxane (PMHS) and Pd-C in THF produced the naturally occurring dihydroisoparthenin (5) ${ }^{11}$ in excellent yield (91\%). The present method is highly efficient and convenient for the preparation of the compound. Parthenin (1) was also reacted with $\mathrm{HCOONH}_{4}$ and $\mathrm{Pd}-\mathrm{C}$. Three products were obtained. Two of them are the natural pseudoguaianolides, dihydroisoparthenin $(5)^{10}$ and dihydrocoronopilin (6), ${ }^{11,12}$ while the third product (7) is the known diastereoisomer of the latter (6). ${ }^{12}$ The $\alpha$-methylene- $\gamma$ butyrolactone moiety (ring C) of the parent compound, 1 was affected in all of these three products, 5-7. The retention of the ring $\mathrm{C}$ of 1 was also not observed when it was treated with $\mathrm{NaBH}_{4}$ and $\mathrm{CoCl}_{2} \cdot 6 \mathrm{H}_{2} \mathrm{O}$ in aqueous medium. The conversion afforded an interesting hexahydro derivative, 8. The structure of the compound was derived from its spectral ( ${ }^{1} \mathrm{H}$ NMR and MS) and analytical data. The configurations of OH-4 and Me-13 were concluded to be в and $\alpha$ respectively as the NOESY experimental showed that Me-15 was correlated with H-11 but not 
with H-4. Compound $\mathbf{8}$ is the 10-deoxy derivative of the recently isolated new pseudoguaianolide, hysterone $\mathrm{D},{ }^{13}$ which upon acetylation with $\mathrm{Ac}_{2} \mathrm{O}$ and pyridine yielded the monoacetate $\mathbf{9}$.



$6 \mathrm{Me}-13 \alpha$

$7 \mathrm{Me}-13$ в

Reagents and Conditions: i. $\mathrm{Ac}_{2} \mathrm{O} / \mathrm{NaHSO} 4 . \mathrm{SiO} 2, \mathrm{CH} 2 \mathrm{Cl} 2$, r.t., 2.5 hours, 94 \%; ii. TMOF/ $\mathrm{NaHSO} 4 . \mathrm{SiO} 2, \mathrm{CH} 2 \mathrm{Cl} 2$, r.t., overnight, $43 \%$; iii. $\mathrm{NaN}_{3} / \mathrm{CAN}, \mathrm{MeOH}$, r.t., overnight, 52 \%; iv. PMHS/Pd-C, THF, r.t., 3 hours, 91 \%; v. HCOONH $4 / \mathrm{Pd}-\mathrm{C}, \mathrm{MeOH}$, r.t., 2 hours, 19 \% (5), 14 \% (6), $17 \%$ (7); vi. $\mathrm{NaBH}_{4} / \mathrm{CoCl}_{2} \cdot 6 \mathrm{H}_{2} \mathrm{O}, \mathrm{H}_{2} \mathrm{O}$, r.t., 2 hours, $38 \%$; vii. Ac $\mathrm{Ac}_{2} \mathrm{O} /$ py, $\Delta, 3$ hours, $82 \%$.

Scheme 1. Chemical Modifications of Parthenin (1).

Table 1. Antibacterial Activity of Parthenin and its Analogues*

\begin{tabular}{|c|c|c|c|c|c|}
\hline Compound & $\begin{array}{c}\text { Bacillus } \\
\text { subtilis }\end{array}$ & $\begin{array}{l}\text { Bacillus } \\
\text { sphaericus }\end{array}$ & $\begin{array}{c}\text { Staphylococcus } \\
\text { aureus }\end{array}$ & $\begin{array}{l}\text { Klebsiella } \\
\text { aerogenes }\end{array}$ & $\begin{array}{l}\text { Chromo- } \\
\text { bacterium } \\
\text { violaceum }\end{array}$ \\
\hline
\end{tabular}




\begin{tabular}{cccccccccccccc}
\hline $\mathrm{a}$ & \multicolumn{1}{c}{$\mathrm{b}$} & $\mathrm{a}$ & \multicolumn{3}{c}{$\mathrm{b}$} & $\mathrm{a}$ & $\mathrm{b}$ & $\mathrm{a}$ & $\mathrm{b}$ & $\mathrm{a}$ & $\mathrm{b}$ \\
$\mathbf{1}$ & 13 & 18 & 6 & 9 & 11 & 14 & 9 & 12 & 10 & 13 \\
$\mathbf{2}$ & 10 & 14 & 8 & 11 & 7 & 10 & 8 & 11 & 8 & 12 \\
$\mathbf{3}$ & 11 & 14 & 8 & 12 & 8 & 11 & 9 & 12 & 11 & 14 \\
$\mathbf{4}$ & 7 & 10 & 7 & 9 & 8 & 11 & 7 & 11 & 7 & 12 \\
$\mathbf{6}$ & 8 & 10 & 8 & 13 & 8 & 12 & 8 & 12 & 9 & 12 \\
Pencillin G & & 15 & & 14 & & 12 & & & & \\
Streptomycin & & & & & & & & & & & & \\
\hline
\end{tabular}

* Results were counted after 24 hours and inhibition zones were measured in millimiters.

a: compound with a concentration of $30 \mu \mathrm{g} / \mathrm{ml}$ was tested against the organism.

b: compound with a concentration of $100 \mu \mathrm{g} / \mathrm{ml}$ was tested against the organism.

The antibacterial activity of compounds 1-9 was examined against different gram-positive (Bacillus subtilis, Bacillus spharicus, Staphylococcus aureus) and gram-negative organisms (Klebsiella aerogenes, Chromobacterium violaceum) (Table 1). The activity was studied by following the Agar cup bioassay method employed ${ }^{14}$ earlier by us. It was observed that the overall activity of parthenin itself was better than that of its analogues. The compound showed very good activity against $B$. subtilis and $S$. aureus and moderate activity against the other organisms. Compounds $\mathbf{2}$ and $\mathbf{3}$ showed comparable activity against $B$. subtilis while compounds 4 and 6 showed moderate activity. All of these four compounds (2-4 and 6) were also found to exhibit moderate activity against all other tested organisms. However, the analogues 5-7, 8 and 9 did not show any activity. It can be noted from this observation that all of the compounds (1-4) having an intact $\alpha$-methylene- $\gamma$-butyrolactone moiety (ring $\mathrm{C}$ ) exhibited antibacterial activity, while the compounds 5 and 7-9 where this ring was not retained were devoid of this activity. An exception is compound 6, which showed moderate antibacterial activity though its ring $\mathrm{C}$ was not intact.

In conclusion, nine analogues have been prepared from the naturally abundant pseudoguaianolide, parthenin employing regio- and stereoselective modifications. Three of these analogues are naturally occurring compounds. The examination of the antibacterial properties revealed that parthenin itself and some of its analogues possess significant activity. The $\alpha$ methylene- $\gamma$-butyrolactone ring was assumed to play an important role for the activity of the compounds.

\section{Experimental Section}

General Procedures. Melting points were measured in a Buchi-510 instrument and are uncorrected. Spectra were recorded with the following instruments: IR:, Nicolet 740 FTIR 
spectrophotometer; 1H NMR: Varian Gemini 200 MHz and MS: VG Micromass 7070 H (70 eV) and VG-Autospec M. Optical rotations were determined with a Jasco DIP 360 digital polarimeter. Column chromatography was performed on silica gel (BDH 100-200 mesh) and TLC with silica gel GF 254. The spots were detected in an iodine chamber and under UV light.

Conversion of Parthenin (1) into anhydroparthenin (2). $\mathrm{Ac}_{2} \mathrm{O}(1 \mathrm{ml})$ was added to a stirred solution of parthenin (1) $(100 \mathrm{mg}, 0.382 \mathrm{mmol})$ in $\mathrm{CH}_{2} \mathrm{Cl}_{2}(10 \mathrm{ml})$. After $5 \mathrm{~min}$. $\mathrm{NaHSO}_{4} \cdot \mathrm{SiO}_{2}$ (300 mg) was added and stirring was continued for 2.5 hours at room temperature. The mixture was filtered. The filtrate was concentrated and subjected to column chromatography over silica gel using hexane-EtOAc (9:1) as eluent to yield anhydroparthenin (2) (89 mg, 94\%).

Reaction of Parthenin (1) with TMOF/NaHSO ${ }_{4} \cdot \mathrm{SiO}_{2}$. TMOF $(0.5 \mathrm{ml})$ in $\mathrm{CH}_{2} \mathrm{Cl}_{2}(5 \mathrm{ml})$ and $\mathrm{NaHSO}_{4} \cdot \mathrm{SiO}_{2}(200 \mathrm{mg})$ were successively added to a solution of parthenin (1) (100 mg, 0.382 $\mathrm{mmol})$ in $\mathrm{CH}_{2} \mathrm{Cl}_{2}(10 \mathrm{ml})$. The mixture was stirred overnight at room temperature. Then, it was filtered and the concentrated filtrate was purified by column chromatography over silica gel using hexane-EtOAc (9:1) as eluent to afford $2 \alpha$-methoxyparthenin (3) (48 mg, 43 \%).

Reaction of Parthenin (1) with $\mathrm{NaN}_{3} / \mathrm{CAN}$. CAN ( $3 \mathrm{mg}, 0.55 \mathrm{mmol}$ ) was added to a solution of parthenin (1) (100 mg, $0.382 \mathrm{mmol})$ and $\mathrm{NaN}_{3}(80 \mathrm{mg}, 1.23 \mathrm{mmol})$ in $\mathrm{MeOH}(15 \mathrm{ml})$. The mixture was stirred overnight at room temperature. $\mathrm{MeOH}$ was removed and the residue was extracted with $\mathrm{CH}_{2} \mathrm{Cl}_{2}(3 \times 20 \mathrm{ml})$. The extract was washed with water $(3 \times 20 \mathrm{ml})$, dried, concentrated and purified by column chromatography over silica gel using hexane-EtOAc $(9: 1)$ as eluent to obtain $2 \alpha$-azidocoronopilin (4) (62 mg, 52\%) as a white solid, m.p. $178-181^{\circ} \mathrm{C}$; optical rotation $[\alpha]_{\mathrm{D}}^{25}:(+) 29.16(\mathrm{c}=0.8, \mathrm{MeOH})$. IR $(\mathrm{KBr}): 3480,1755,1720,1660 \mathrm{~cm}^{-1} .{ }^{1} \mathrm{H}$ NMR (200 MHz, CDCl $)$ ): $\delta 6.18(1 \mathrm{H}, \mathrm{d}, J=2.2 \mathrm{~Hz}, \mathrm{H}-13 \mathrm{a}), 5.59(1 \mathrm{H}, \mathrm{d}, J=2.2 \mathrm{~Hz}, \mathrm{H}-13 \mathrm{~b}), 4.88$ $(1 \mathrm{H}, \mathrm{d}, J=8.0 \mathrm{~Hz}, \mathrm{H}-6), 4.46$ (1H, dd, J=9.8, $8.0 \mathrm{~Hz}, \mathrm{H}-2), 3.39$ (1H, m, H-7), 2.78 (1H, dd, $J=17.5,8.0$ Hz, H-3a), 2.48 (2H, m, H-3b, H-8a), 2.20-1.64 (4H, m, H-8b, H2-9, H-10), 1.18 $(3 \mathrm{H}, \mathrm{d}, J=7.0 \mathrm{~Hz}, \mathrm{Me}-14), 1.10$ (3H, s, Me-15). MS (LSI): m/z $328\left(\mathrm{M}^{+}+23\right)$. Found: C, 59.14; $\mathrm{H}, 13.86$; N, 6.32: Calcd. For $\mathrm{C}_{15} \mathrm{H}_{19} \mathrm{~N}_{3} \mathrm{O}_{4}$ : C, 59.01; H, 13.76; N, $6.27 \%$.

Reduction of Parthenin (1) with PMHS/Pd-C. To a stirred solution of parthenin (1) (100 mg, $0.382 \mathrm{mmol})$ in THF (10 ml) PMHS $(60 \mathrm{mg}, 1.0 \mathrm{mmol})$ and Pd-C (5 mg) were added. The mixture was stirred at room temperature. After 3 hours the mixture was filtered and the filtrate was extracted with $\mathrm{CH}_{2} \mathrm{Cl}_{2}(3 \times 10 \mathrm{ml})$. Evaporation of the volatiles followed by column chromatography over silica gel using hexane-EtOAc (9:1) afforded dihydroisoparthenin (5) (92 $\mathrm{mg}, 91 \%$ ).

Reduction of Parthenin (1) with $\mathrm{HCOONH}_{4} / \mathbf{P d - C}$. To a stirred solution of parthenin (1) (200 $\mathrm{mg}, 0.76 \mathrm{mmol})$ in dry $\mathrm{MeOH}(15 \mathrm{ml})$ 10\% Pd-C (20 mg) and dry $\mathrm{HCOONH}_{4}(315 \mathrm{mg}, 5 \mathrm{mmol})$ were added under $\mathrm{N}_{2}$. The mixture was stirred for 2 hours at room temperature and filtered. The filtrate was concentrated and the residue was extracted with $\mathrm{CH}_{2} \mathrm{Cl}_{2}(3 \times 15 \mathrm{ml})$. The concentrated extract was subjected to column chromatography over silica gel using hexane-EtOAc $(9: 1)$ as eluent to afford the naturally occurring compounds, dihydroisoparthenin (5) (38 mg, 19\%) and 
dihydrocoronopilin (6) (28 mg, $14 \%$ ) along with 7, (35 mg, $17 \%$ ), the known diastereoisomer of the latter.

Reduction of Parthenin (1) with $\mathrm{NaBH}_{4} / \mathrm{CoCl}_{2} \cdot \mathbf{6 H} \mathrm{H}_{2} \mathrm{O}$. To a stirring mixture of parthenin (1) (100 mg, $0.382 \mathrm{mmol})$ and $\mathrm{CoCl}_{2} \cdot 6 \mathrm{H}_{2} \mathrm{O}(0.048 \mathrm{mg}, 0.2 \mathrm{mmol})$ a solution of $\mathrm{NaBH}_{4}(148 \mathrm{mg}, 4$ mmol) in $\mathrm{H}_{2} \mathrm{O}(4 \mathrm{ml})$ was added dropwise. The mixture was stirred for 2 hours and extracted with $\mathrm{CH}_{2} \mathrm{Cl}_{2}(3 \times 10 \mathrm{ml})$. Evaporation of the volatiles followed by column chromatography over silica gel using hexane-EtOAc (4:1) produced 10-deoxyhysterone D (8) (38 mg, $38 \%$ ) as a white solid, m.p. 122- $124^{\circ} \mathrm{C}$; optical rotation [ $\alpha$ ]D25: - 20.45 (c=0.2, MeOH). IR (KBr): 3440, 1722, $1460 \mathrm{~cm}^{-1} .{ }^{1} \mathrm{H}$ NMR $\left(200 \mathrm{MHz}, \mathrm{CDCl}_{3}\right): \delta 5.10(1 \mathrm{H}, \mathrm{d}, J=8.0 \mathrm{~Hz}, \mathrm{H}-6), 4.52(1 \mathrm{H}, \mathrm{t}, J=8.0 \mathrm{~Hz}, \mathrm{H}-$ 4), 2.43 (1H, m, H-11), 2.30-1.51 (10H, m, H $\left.-2, \mathrm{H}_{2}-3, \mathrm{H}-7, \mathrm{H}_{2}-8, \mathrm{H}_{2}-9, \mathrm{H}-10\right), 1.23$ (3H, d, $J=7.0 \mathrm{~Hz}, \mathrm{Me}-13), 1.08$ (3H, d, J=7.0 Hz, Me-14), 1.00 (3H, s, Me-15). MS (LSI): m/z $291\left(\mathrm{M}^{+}\right.$. +23). Found: C, 63.46; H, 8.51: Calcd. For $\mathrm{C}_{15} \mathrm{H}_{24} \mathrm{O}_{4}$ : C, 63.39; H, 8.61\%.

Acetylation of 10-deoxyhysterone D (8). A mixture of 10-deoxyhysterone D (8) (10 mg, 0.037 $\mathrm{mmol}), \mathrm{Ac}_{2} \mathrm{O}(1.0 \mathrm{ml})$ and pyridine $(0.02 \mathrm{ml})$ was refluxed for 3 hours. Usual work-up afforded the acetylated product 9 (9 mg, $82 \%)$. IR (KBr): 3446, 1730, $1721 \mathrm{~cm}^{-1} .{ }^{1} \mathrm{H}$ NMR $(200 \mathrm{MHz}$, $\left.\mathrm{CDCl}_{3}\right): \delta 5.43(1 \mathrm{H}, \mathrm{t}, J=8.0 \mathrm{~Hz}, \mathrm{H}-4), 5.12(1 \mathrm{H}, \mathrm{d}, J=8.0 \mathrm{~Hz}, \mathrm{H}-6), 2.45$ (1H, m, H-11), 2.381.47 (10H, m, H2-2, H2-3, H-7, H $\left.\mathrm{H}_{2}-8, \mathrm{H}_{2}-9, \mathrm{H}-10\right), 1.22$ (3H, d, J=7.0 Hz, Me-13), 1.11 (3H, d, $J=7.0 \mathrm{~Hz}, \mathrm{Me}-14), 1.02$ (3H, s, Me-15). MS (LSI): m/z $333\left(\mathrm{M}^{+}+23\right)$.

\section{References and Notes}

1. Part 22 In the series Synthetic Studies on Natural Products.

2. Herz, W.; Watanabe, H.; Miyazaki, M.; Kishida. Y. J. Am. Chem. Soc. 1962, 84, 2601.

3. Hopper, M.; Kirby, G.C.; Kulkarni, M.M.; Kulkarni, S.N.; Nagasampagi, B.A.; O' Neill, M.J.; Philipson. J.D.; Rojatkar, S.R.; Warhurs, D.C. Eur. J. Med. Chem. 1990, 25, 717.

4. Sharma, G.L.; Bhutani M.M. Planta Med. 1988, 54, 120.

5. (a) Kanchan, S.D. Curr. Sci. 1975, 44, 358. (b) Patil, T.M.; Hedge, B.A. Curr. Sci. 1988, 57, 1178.

6. Breton, G.W. J. Org. Chem. 1997, 62, 8952.

7. Das, B.; Das, R. Allelopathy J. 1995, 2, 99.

8. Bhat, U.G.; Nagasampagi, B.A. Indian J. Chem. 1988, 27B, 989.

9. Samek, Z.; Holub, M.; Navikov, V.J.; Forostjan, J.N.; Dopa D.P. Coll. Czech. Chem. Commun. 1970, 35, 3818.

10. Picman, A.K.; Blaza, F.; Towers, G.G.N. Phytochemistry 1982, 21, 1801.

11. Geissman, T.A.; Toribio, F.P. Phytochemistry 1967, 6, 1563.

12. Ruesh, H.; Mabry, T.J. Tetrahedron 1969, 25, 805.

13. Ramesh, C.; Ravindranath, N.; Das, B.; Prabhakar, A.; Bharatam, J.; Ravikumar, K.; Kashinatham, A.; McMorris, T.C. Phytochemistry 2003 (in press). 
14. Srinivas, K.V.N.S.; Rao, Y.K., Mahender, I.; Das, B.; Krishna, K.V.S.R.; Kishore, K.H.; Murty, U.S.N. Phytochemistry 2003, 63, 789. 